\title{
PENINGKATAN MOTIVASI DAN HASIL BELAJAR SISWA PADA MATA PELAJARAN IPS KELAS VIII MELALUI MEDIA AUDIO VISUAL DI MTS AL- ABROR BLUMBUNGAN PAMEKASAN
}

\author{
Muti'ah Febrianti \\ Program Studi Tadris IImu Pengetahuan Sosial \\ Fakultas Tarbiyah Institut Agama Islam Negeri Madura \\ mutyafebryanty@gmail.com \\ Siti Azizah \\ Program Studi Tadris IImu Pengetahuan Sosial, \\ Fakultas Tarbiyah, Institut Agama Islam Negeri Madura \\ azizahstainpmk@yahoo.com
}

\begin{abstract}
Abstrak
Media audio visual adalah media instruksional modern yang sesuai dengan perkembangan zaman, meliputi media yang dapat dilihat, didengar dan yang dapat dilihat dan didengar. Penekanan utama dalam pengajaran audio visual adalah pada nilai belajar yang diperoleh melalui pengalaman kongkret, tidak hanya didasarkan pada kata-kata belaka.Berdasarkan hal tersebut, maka masalah yang dikaji dalam penelitian ini adalah: pertama, Bagaimana penggunaan media audio visual dapat meningkatkan motivasi belajar pada mata pelajaran IPS di kelas VIII MTs Al-Abror. Kedua, Bagaimana meingkatkan hasil belajar siswa kelas VIII MTs Al-Abror pada mata pelajaran IPS dengan menggunakan media audio visual. Apa saja nilai-nilai nasionalisme yang terkandung dalam mata pelajaran IPS. Dari permasalahan tersebut tujuan dari penelitian ini adalah untuk: (1) mengetahui penggunaan media audio visual dalam meningkatkan motivasi belajar mata pelajaran IPS pada siswa kelas VIII di MTs Al-Abror Blumbungan Pamekasan, (2) mengetahui penggunaannya dalam meningkatkan hasil belajar mata pelajaran IPS pada siswa kelas VIII di MTs AlAbror Blumbungan Pamekasan.Untuk mencapai tujuan diatas, penelitian ini menggunakan jenis penelitian Penelitian Tindakan Kelas (PTK) sedangkan tekhnik pengumpulan data menggunakan teknik observasi, dokumentasi, dan test. Sedangkan untuk analisisnya, penulis menggunakan teknik analisis deskriptif kualitatif. Untuk uji keabsahan data penulis menggunakan tiga carayaitu perpanjangan keikutsertaan, ketekunan pengamatan dan triangulasi. Sumber penelitiannya yaitu siswa kelas VIII.
\end{abstract}

Kata Kunci: Media Audio Visual, Motivasi Belajar, Hasil Belajar, Mata Pelajaran IPS

\begin{abstract}
Audio visual media is a modern instructional media that is in accordance with the times, including media that can be seen, heard and which can be seen and heard. The main emphasis in audio visual teaching is on the value of learning obtained through concrete experience, not only based on mere words. Based on this, the problems examined in this study are: first, how the use of audio visual media can increase learning motivation in social studies subjects in class VIII MTs Al-Abror. Second, how to improve the learning outcomes of students of class VIII MTs Al-Abror in social studies subjects using audio visual media. What are the values of nationalism contained in social studies subjects. From these problems the purpose of this study is to: (1) find out the use of audio-visual media in increasing motivation to study social studies subjects in class VIII students at MTs Al-Abror Blumbungan Pamekasan, (2) knowing their use in improving the learning outcomes of social studies subjects in Grade VIII students at Al-Abror Blumbungan Pamekasan MTs. To achieve the above objectives, this study uses a Classroom Action Research (CAR) research while data collection techniques use observation, documentation, and test techniques. As for the analysis, the writer uses descriptive qualitative analysis techniques. To test the validity of the data the author uses three ways, namely the extension of participation, perseverance of observation and triangulation. The source of his research is VIII grade students.
\end{abstract}

Keyword: Audio Visual Media, Learning Motivation, Learning Outcomes, Social Studies Subjects 


\section{PENDAHULUAN}

Motivasi adalah suatu keadaan seseorang yang mempunyai semangat tinggi, rajin, mampu bekerja keras yang akhirnya mengantarkan seseorang pada pencapaian yang memuaskan atau bahkan pencapaian prestasi. Dalam proses belajar, motivasi sangatlah diperlukan sebab seseorang yang tidak memiliki motivasi dalam belajar tidak akan mungkin melakukan aktivitas berlajar.

Belajar dan motivasi selalu mendapat perhatian khusus bagi pendidik dan peserta didik, karena memberi motivasi kepada peserta didik merupakan hal yang perlu dan penting dalam proses pembelajaran. $\mathrm{Di}$ sekolah, setiap anak memiliki sejumlah motivasi atau dorongan-dorongan yang berhubungan dengan kebutuhan, baik kebutuhan biologis maupun kebutuhan psikologis. Disamping itu anak juga memiliki sikap-sikap, minat-minat, penghargaan dan tujuan-tujuan tertentu. Oleh sebab itu, tugas guru adalah menimbulkan motivasi yang akan mendorong anak untuk berbuat sesuatu dalam mencapai tujuan belajarnya.

Para guru dituntut agar mampu menggunakan alat-alat yang dapat disediakan oleh sekolah dan tidak tertutup kemungkinan bahwa alat-alat tersebut sesuai dengan perkembangan dan tuntutan zaman. Guru sekurang-kurangnya dapat menggunakan alat yang murah dan efisien yang meskipun sederhana dan bersahaja tetapi merupakan suatu keharusan dalam upaya mencapai tujuan pengajaran yang diharapkan. ${ }^{1}$

Media pembelajaran merupakan salah satu unsur yang sangat penting dalam proses belajar mengajar yang dapat dimuati pesan yang akan disampaikan kepada siswa, baik berupa alat, orang maupun bahan ajar. Selain itu media pembelajaran merupakan salah satu cara untuk memotivasi dan berkomunikasi dengan siswa agar lebih efektif. ${ }^{2}$ Oleh karena itu media pembelajaran saat proses belajar mengajar sangat diperlukan.

\section{METODE}

Pada dasarnya bagian ini menjelaskan bagaimana penelitian itu dilakukan. Materi pokok bagian ini adalah: (1) rancangan penelitian; (2) sumber data; (3) teknik pengumpulan data; (4) dan analisis data. Untuk penelitian yang menggunakan alat dan

\footnotetext{
${ }^{1}$ Azhar Arsyad,Media Pembelajaran ( Jakarta:Raja Grafindo,2002), hal 2

${ }^{2}$ Ahmad Susanto, Pengembangan Pembelajaran IPS (Jakarta:Prenadamedia Group,2016), hal 313-314
}

bahan, perlu dituliskan spesifikasi alat dan bahannya. Spesifikasi alat menggambarkan kecanggihan alat yang digunakan sedangkan spesifikasi bahan menggambarkan macam bahan yang digunakan.

Untuk penelitian kualitatif seperti penelitian tindakan kelas, etnografi, fenomenologi, studi kasus, dan lain-lain, perlu ditambahkan kehadiran peneliti, subyek penelitian, informan yang ikut membantu beserta cara-cara menggali data-data penelitian, lokasi dan lama penelitian serta uraian mengenai pengecekan keabsahan hasil penelitian.

Sebaiknya dihindari pengorganisasian penulisan ke dalam "anak sub-judul" pada bagian ini. Namun, jika tidak bisa dihindari, cara penulisannya dapat dilihat pada bagian "Hasil dan Pembahasan".

Pendekatan penelitian yang digunakan dalam PTK ini adalah pendekatan kualitatif, sebab dalam melakukan kepada subyek penelitian, yang sangat diutamakan adalah mengungkap makna, yakni makna dan proses pembelajaran sebagai upaya meningkatkan motivasi dan hasil belajar, kegairahan dan prestasi belajar melalui tindakan yang dilakukan. Penelitian tindakan kelas yaitu suatu tindakan yang dilakukan oleh guru/pelaku, mulai dari perencanaan sampai dengan penilaian terhadap tindakan nyata di dalam kelas yang berupa kegiatan belajarmengajar untuk memperbaiki kondisi pembelajaran yang dilakukan. ${ }^{3}$ Sedangkan tempat penelitian dilakukan di MTs Al-Abror Blumbungan untuk mata pelajaran IPS.

PTK ini dilakukan melalui tiga siklus untuk melihat peningkatan hasil belajar dan aktifitas siswa dalam mengikuti mata pelajaran IImu Pengetahuan Sosial dalam penerapan media audio visual. Namun apabila dalam siklus pertama sudah berhasil maka akan dilakukan dua siklus saja. Dalam PTK ini yang menjadi subyek penelitian adalah siswa kelas VIII yang terdiri dari 25 siswa.

Teknik pengumpulan data dalam penelitian ini yaitu pengumpulan data melalui pertanyaan. Sedangkan alat pegumpulan data berupa observasi: Observasi: menggunakan lembar observasi untuk mengukur tingkat aktifitas siswa dalam dalam proses pembelajaran IPS.

\footnotetext{
${ }^{3}$ Siti Halifah Magorani, "Meningkatkan Hasil Belajar Siswa Melalui Penggunaan Media Gambar Pada Pembelajaran IPS di Kelas IV SDN Tou Kabupaten Banggai”. Jurnal Kreatif Tadulako Online No. 11,. HIm.169
} 


\section{HASIL DAN PEMBAHASAN}

Dari hasil penelitian siklus pertama sampai dengan siklus ketiga, ada peningkatan yang signifikan dalam motivasi belajar siswa. Terlihat dari nilai observasi motivasi dan nilai pre-tes, post test pertama, kedua dan nilai ulangan. Pada siklus pertama, nilai motivasi menunjuk pada angka persentase nilai $48 \%$. Siklus kedua menunjukkan peningkatan nilai motivasi sebesar $71 \%$. Selanjutnya pada siklus ketiga menunjukkan nilai rata-rata motivasi $89 \%$.

Untuk hasil belajar siswa juga mengalami peningkatan yang signifikan. Pada nilai pre test, siswa hanya mendapat nilai persentase ketuntasan $48 \%$ dengan nilai rata-rata 72,5 . Sedangkan pada hasil post test pertama menunjukkan peningkatan nilai persentase ketuntasan sebesar $84 \%$ dengan rata-rata 79,4 . Untuk post test kedua juga mengalami peningkatan persentase ketuntasan hingga $100 \%$ dengan rata-rata 85 . Peneliti juga mengadakan ulangan harian untuk melihat seberapa tingkat kepahaman siswa dan menunjukkan nilai rata-rata sebesar 85,6 . Dan persentase ketuntasan mencapai $100 \%$ benarbenar telah mencapai target indicator pencapaian dalam penelitian ini. Dari hasil rata-rata siswa dan persentase siswa yang tuntas telah menunjukkan ketercapaian indikator yang peneliti harapkan, sehingga penelitian ini dapat dikatakan positif dan bermanfaat bagi siswa.

Tabel 1. hasil Pre Test dan Post Test

\begin{tabular}{|c|l|c|c|c|}
\hline $\begin{array}{c}\text { N } \\
\mathbf{0}\end{array}$ & \multicolumn{1}{|c|}{ Nama } & I & II & III \\
\hline 1 & Afiyah Sukardi Putri & 75 & 80 & 85 \\
\hline 2 & Eka Julia Trisna & 65 & 75 & 80 \\
\hline 3 & Farhatin & 65 & 70 & 80 \\
\hline 4 & Fifi Mustaghfiroh & 70 & 80 & 85 \\
\hline 5 & Imroatul Mufida & 75 & 85 & 90 \\
\hline 6 & Lailatul Fajriyah & 80 & 75 & 80 \\
\hline 7 & Lilis Handayani & 65 & 70 & 85 \\
\hline 8 & Nafa Ainiyatus Salimah & 85 & 95 & 95 \\
\hline 9 & Qurrotul Uyuni & 70 & 80 & 85 \\
\hline 10 & Radhiyatus Sari & 65 & 75 & 80 \\
\hline 11 & Shafiyatul Atiyah & 75 & 85 & 85 \\
\hline 12 & Faizatur Rahmah & 85 & 90 & 95 \\
\hline 13 & Ach. Hasbullah & 75 & 75 & 80 \\
\hline 14 & Ach. Siddiki & 65 & 80 & 85 \\
\hline 15 & Aliv Firmansyah & 65 & 70 & 85 \\
\hline 16 & Ainul Yakin & 70 & 80 & 80 \\
\hline 17 & Aji Pramono & 80 & 80 & 85 \\
\hline 18 & Doni Firmansyah & 75 & 80 & 85 \\
\hline
\end{tabular}

Peningkatan Motivasi Dan Hasil Belajar Siswa Pada Mata Pelajaran Ips Kelas Viii Melalui Media Audio Visual Di Mts AlAbror Blumbungan Pamekasan

\begin{tabular}{|c|l|c|c|c|}
\hline 19 & $\begin{array}{l}\text { Galih Firdaus Dwi } \\
\text { Santoso }\end{array}$ & 70 & 75 & 85 \\
\hline 20 & Holilurrahman & 80 & 95 & 95 \\
\hline 21 & lqbalul Haq & 75 & 80 & 85 \\
\hline 22 & Saddat Hidayatullah & 85 & 85 & 85 \\
\hline 23 & Ubaydillah & 65 & 80 & 85 \\
\hline 24 & Firman Hidayat & 70 & 75 & 85 \\
\hline 25 & Ahmad NurHafidz & 65 & 70 & 80 \\
\hline \multicolumn{2}{|l|}{ JUMLAH } & 1,81 & 1,98 & 2,12 \\
\hline \multicolumn{2}{|l|}{ RATA-RATA } & 5 & 5 & 5 \\
\hline
\end{tabular}

Fokus dalam penelitian ini adalah penggunaan media audio visual untuk meningkatkan motivasi dan hasil belajar pada pembelajaran IPS dengan materi tentang perkembangan masyarakat Indonesia pada masa kolonialisme dan imperialisme serta tumbuhnya semangat kebangsaan. Penelitian ini dilakukan dengan dua penelitian, penelitian dilaksanakan empat kali siklus, hal ini mengingat materi yang akan diajarkan hanya kolonialisme dan imperialisme bangsa barat di Indonesia. Penelitian pertama, pada siklus pertama peneliti melaksanakan pemeriksaan lapangan dan memberikan pre test menggunakan strategi pembelajaran konvensional dengan metode ceramah dan tanya jawab. Guru menjelaskan, mendekte di depan kelas, sedangkan siswa mendengarkan dan menulis apa yang diperintahkan guru, serta diselingi tanya jawab. Melalui pre test, dapat diketahui bahwa pembelajaran konvensional dengan metode ceramah dan tanya jawab menjadikan siswa pasif dan menjadikan guru sebagai satu-satunya pentransfer ilmu. Siswa tidak dituntut untuk mencari sendiri dan memecahkan masalah dalam kegiatan pembelajaran. Sehingga siswa cenderung tidak semangat dan motivasi belajar siswa sangat rendah, karena hanya menjadi pendengar saja dan tidak terlalu ikut andil dalam pembelajaran.

Dari hasil pre test yang telah dilaksanakan, siswa tampak kurang antusias dan kurang berminat dalam pembelajaran IPS. Hal ini dapat diamati pada lembar observasi motivasi yang menunjuk pada persentase $48 \%$ yang mengindikasikan bahwa siswa masih kurang berminat pada pembelajaran IPS, dan hasil pada ranah kognitif menunjukkan nilai rata-rata 72,5 dengan persentase ketercapaian hanya $48 \%$ yang mengindikasikan nilai siswa masih banyak yang belom mencapai KKM.

Pembelajaran yang kurang melibatkan siswa dalam kegiatan pembelajaranakan menimbulkan rasa terpaksa, tertekan, bosan dan malas. Sehingga mengakibatkan motivasi 
belajar siswa menjadi menurun. Jadi sudah jelas bahwa metode ceramah dan tanya jawab sangat tidak kondusif jika diterapkan dalam kegiatan pembelajaran yang cenderung membutuhkan cerita yang realita seperti pelajaran IPS. Salah satu cara menciptakan lingkungan belajar yang menyenangkan dalam pembelajaran IPS khususnya pada materi tentang kondisi masyarakat indonesia pada masa kolonialisme dan imperialisme bangsa barat adalah dengan menggunakan media video. Dimana media tersebut diharapkan mampu menggugah semangat dan meningkatkan motivasi belajar siswa dalam pembelajaran. Karena dengan media tersebut siswa dapat melihat kejadian peristiwaperistiwa secara kongkrit, bukan hanya sekedar mengetahui dari cerita.

Menyikapi hasil pre test, pada siklus selanjutnya peneliti menggunakan media video. Dengan menggunakan media ini diharapkan siswa mampu berperan aktif dalam mengikuti pembelajaran IPS di kelas. Dengan media video kebutuhan berbagai program pendidikan dapat dipenuhi dengan baik, berbagai sumber informasi yang tidak mungkin diberikan melalui media lainnya dapat disajikan melalui video. Alat ini dapat diputar kembali yang memungkinkan terjadinya proses umpan balik untuk perbaikan dan peningkatan upaya pengajaran.

Dengan media video kebutuhan berbagai program pendidikan dapat dipenuhi dengan baik, berbagai sumber informasi yang tidak mungkin diberikan melalui media lainnya dapat disajikan melalui video. Alat ini dapat diputar kembali yang memungkinkan terjadinya proses umpan balik untuk perbaikan dan peningkatan upaya pengajaran. ${ }^{4}$

Video, sebagai media audio-visual yang menampilkan gerak, semakin lama semakin popular dalam masyarakat kita. Pesan yang disajikan bersifat fakta (kejadian/ peristiwa penting, berita) maupun fiktif (cerita), bisa bersifat informatif, edukatif maupun instruksional. Sebagian besar tugas film dapat digantikan video. Tapi ini tidak berarti bahwa video akan menggantikan kedudukan film. Masing-masing mempunyai kelebihan dan keterbatasannya sendiri.

Penggunaaan media tersebut dalam pertemuan kedua pada penelitian initernyata menjadikan siswa lebih berani mengungkapkan pendapatnya dan lebih

${ }^{4}$ R.Ibrahim dan nana Syaodih, Perencanaan Pengajaran, (Jakarta: Rineka Cipta, 2003), hal. 117-118 bersemangat dibanding dengan pertemuan sebelumnya. Ada keinginan untuk belajar IPS yang ditunjukkan dengan mengungkapkan pendapat dan bertanya walaupun sebagian besar masih didominasi oleh siswa yang aktif.

Hasil observasi pertemuan kedua dilakukan pada saat pembelajaran berlangsung maupun di luar jam pelajaran. Setelah dilakukan penelitian dapat diamati pada lembar motivasi belajar menunjuk pada persentase $71 \%$ yang mengindikasikan adanya peningkatan motivasi belajar terhadap pelajaran IPS, pada ranah kognitif juga terlihat ada peningkatan yakni hingga $84 \%$ dengan rata-rata nilai 79,4 yang sudah melampaui batas nilai KKM.

Dari hasil pelaksanaan penelitian siklus ketiga, setelah peneliti melakukan observasi pada saat pembelajaran berlangsung maupun diluar jam pelajaran. Dapat dilihat pada lembar observasi motivasi menunjuk pada persentase nilai mencapai angka $89 \%$ yang mengindikasikan adanya peningkatan motivasi belajar terhadap pelajaran IPS, pada ranah kognitif menunjukkan pada rata-rata nilai 85 dan persentase ketuntasan nilai siswa $100 \%$. Dapat diketahui bahwa motivasi dan hasil belajar siswa mengalami peningkatan yang cukup tinggi. Jadi hasil observasi lapangan menunjukkan adanya peningkatan motivasi dari siklus kedua dan ketiga.

\section{Berdasarkan hasil pengamatan maka penggunaan media video mampu meningkatkan motivasi belajar siswa. Karena penggunaan video sangat sesuai dengan materi yang akan diajarkan yaitu tentang kolonialisme dan imperialisme bangsa barat di Indonesia, dimana materi ini perlu melihat dengan realita yang melibatkan siswa dapat melihat kejadian dan kondisi masyarakat pada waktu itu secara langsung.}

Bukti yang lain adalah pernyataan siswa yang mengatakan senang terhadap penggunaan media video, sehingga kelas lebih hidup dan siswa mulai bersemangat yang ditunjukkan muka sangat ceria dan lebih antusias dalam mengikuti pelajaran IPS.

Dari hasil observasi selama penelitian, terjadi peningkatan yang signifikan, hal ini disebabkan penggunaan media audio visual yang diterapkan oleh peneliti pada pembelajaran IPS pada materi kolonialisme dan imperialisme bangsa barat di indonesia, dapat menggerakkan motivasi belajar siswa. Hal ini selaras dengan hasil observasi saat pembelajaran berlangsung. Siswa sangat antusias dan semangat dalam mengikuti pelajaran. Tidak ada rasa bosan dan jenuh, 
karena siswa terlibat secara aktif dalam kegiatan pembelajaran.

Media audio visual adalah jenis media yang selain mengandung unsur suara juga mengandung unsur gambar yang bisa dilihat. Misalnya rekaman video, berbagai rekaman film, slide suara, dan lain sebagainya. Kemampuan media ini dianggap lebih baik dan lebih menarik. Manfaat media dalam kegiatan pembelajaran tidak lain adalah memperlancar proses interaksi antara guru dengan siswa, dalam hal ini membantu siswa belajar secara optimal. Kedudukan media cukup penting artinya dalam meningkatkan kadar informasi yang kita ingat (70\%) dibandingkan dengan pembelajaran melalui metode ceramah $(20 \%)^{5}$

Motivasi belajar siswa sangat menentukan hasil belajar siswa. Makin tepat motivasi yang diberikan maka akan makin berhasil pula pelajaran itu. Jadi motivasi akan senantiasa menentukan intensitas usaha belajar bagi para siswa. Jadi motivasi belajar pada siswa harus selalu digerakkan dengan cara selalu memberikan metode, strategi dan pendekatan yang variatif agar siswa selalu semangat dalam mengikuti pelajaran. Adapun indikator keberhasilan penggunaan media video sebagai berikut:

1. Pada saat pembelajaran siswa terlihat lebih aktif untuk mencari sendiri, semangat dan tidak merasa bosan pada saat pembelajaran berlangsung.

2. Dengan menggunakan video karena siswa bisa melihat secara realita kondisi masyarakat Indonesia secara langsung dan lebih konsentrasi.

3. Adanya peningkatan motivasi dan hasil belajar siswa terlihat pada saat observasi yang dilakukan oleh peneliti.

\section{PENUTUP}

\section{Simpulan}

Penggunaan media audio visual untuk meningkatkan motivasi belajar siswa kelas VIII MTs Al-Abror Blumbungan Pamekasan dilakukan 3 kali siklus. Penggunaan media audio visual memiliki dampak positif terhadap peningkatan motivasi belajar siswa. Berdasarkan secara kuantitatif berupa angkaangka yang diperoleh dari perhitungan motivasi belajar siswa dapat diketahui bahwa penggunan media audio visual yaitu meningkatnya motivasi belajar siswa dari siklus petama yaitu persentase hasil observasi

${ }^{5}$ Wina Sanjaya, Startegi Pembelajaran Berorientasi Standar Proses Pendidikan, (Jakarta: 2014),hal.172
Peningkatan Motivasi Dan Hasil Belajar Siswa Pada Mata Pelajaran Ips Kelas Viii Melalui Media Audio Visual Di Mts AlAbror Blumbungan Pamekasan

mencapai $48 \%$, pada siklus ke dua mengalami peningkatan sampek $71 \%$ dan pada siklus ketiga mencapai $89 \%$.

Penggunaan media audio visual untuk meningkatkan hasil belajar siswa mata pelajaran IPS pada kelas VIII di MTs Al-Abror Blumbungan Pamekasan dikatakan berhasil dan mengalami peningkatan dengan melihat meningkatnya motivasi belajar siswa pada mata pelajaran IPS dalam materi pelajaran kolonialisme dan imperialisme ditunjang dengan hasil tindakan pre-tes, post tes I, post tes II dan hasil ulangan harian yang mengalami peningkatan secara signifikan. Berdasarkan secara kuantitatif berupa angkaangka yang diperoleh dari perhitungan ratarata nilai hasil belajar siswa dapat diketahui bahwa penggunan media audio visual yaitu meningkatnya hasil belajar siswadari pertemuan petama yaitu pre test 72,5 dengan persentase ketuntasan masih $48 \%$ belum mencapai hasil yang ditargetkan,post test pertama 79,4 dengan persentase $84 \%$, post test kedua 85 dengan persentase mencapai $100 \%$ dan ulangan harian 85,6 persentase $100 \%$. Dari ini dapat disimpulkan bahwa motivasi belajar siswa sangat menentukan hasil belajar siswa.

\section{Saran}

Saran disusun berdasarkan temuan penelitian yang telah dibahas. Saran dapat mengacu pada tindakan praktis, pengembangan teori baru, dan/atau penelitian lanjutan.

Melihat hasil penelitian diatas sebagai saran dari peneliti yang di harapkan adalah dapat menjadi pertimbangan bagi peningkatan mutupendidikan IPS adalah sebagai berikut:

1. Bagi peneliti lain, di sarankan menggunakan media lain yang harus di pahami agar bisa bermanfaat dalam dunia pendidikan. Jika menggunakan media audio visual sebagai penelitian, sebaiknya memperhatikan suara, gambar yang ada di video, sehingga apa yang dibicarakn sesuai dengan apa yang ditunjukkan dalam video.

2. Bagi guru, diharapkan lebih banyak berpikir tentang strategi dan metode apayang harus diterapkan untuk mencapai kompetensi dasar yang ditargetkan. 


\section{DAFTAR PUSTAKA}

Azhar Arsyad. 2002. Media Pembelajaran Jakarta: Raja Grafindo.

Ahmad Susanto, Pengembangan Pembelajaran IPS. 2016. Jakarta :Prenadamedia Group.

Magorani,Siti Halifah. "Meningkatkan Hasil Belajar Siswa Melalui Penggunaan Media Gambar Pada Pembelajaran IPS di Kelas IV SDN Tou Kabupaten Banggai". Jurnal Kreatif Tadulako Online No. 11.

R.Ibrahim dan nana Syaodih. 2003. Perencanaan Pengajaran. Jakarta: Rineka Cipta.

Wina Sanjaya. 2014. Startegi Pembelajaran Berorientasi Standar Proses Pendidikan, Jakarta. 